\title{
EFFECTS OF CENOCOCCUM GEOPHILUM ON THE GROWTH OF SEEDLINGS OF OSTRYOPSIS DAVIDIANA DENCE. AND PINUS TABULEAFORMIS CARR.
}

\author{
Hui Li, Qingzhi Yao*, Ying Tie and HuiYing Zhao \\ Life College of Inner Mongolia Agriculture University, Huhhot, \\ Inner Mongolia 010018, China
}

Keywords: Cenococcum geophilum, Ostryopsis davidiana, Pinus tabulaeformis, ECM

\begin{abstract}
The affinity and promoting ability of the Cenococcum geophilum strains $\left(\mathrm{CgSO}_{1}, \mathrm{CgSB}_{2}, \mathrm{CgO}_{5}, \mathrm{SPOP}_{2}\right.$ and $\mathrm{Cg}_{5}^{\#}$ ) to Ostryopsis davidiana and Pinus tabulaeformis were studied. The results showed that the tested strains formed ectomycorrhizae (ECM) with $O$. davidiana except the $\mathrm{Cg}_{5}{ }^{\#}$ strain and the infection rates were $40-50 \% . \mathrm{CgSO}_{1}$ and $\mathrm{CgSPOP}_{2}$ formed $\mathrm{ECM}$ with $P$. tabulaeformis and the infection rates were 10.3 and $12.4 \%$, respectively. C. geophilum can promote the growth of the two host plant seedlings, especially for root growth. Results proved that the affinity of different strains to host plants and the affinity of the same strain to different host plants are different.
\end{abstract}

\section{Introduction}

Daqing Mountain located in Inner Mongolia is undergoing forest restoration about 400 kilometers west of Beijing, but it is a buffer zone for sandstorms. Therefore, the current vegetation degradation is still serious. Ostryopsis davidiana and Pinus tabulaeformis are widely distributed in the harsh site conditions of Daqing Mountain. O. davidiana belonging to Betulaceae is a special excellent soil protection shrub in China. P. tabulaeformis is a conifer tree species endemic to China and widely distributed in temperate forests of north China (Wang et al. 2017).

Bai et al. (2009) reported that it is difficult for the transplanted seedlings to survive in the absence of mycorrhiza fungi. Compared with fixed-planting seedlings, non-mycorrhizal seedlings lacked drought tolerance and reduced absorption to water and soil nutrient. Moreover, colonization of $O$. davidiana by Cenococcum geophilum was greater than $50 \%$ when the P. tabulaeformis in the two trees mixed forest. This suggests the possibility that $C$. geophilum has higher affinity with $O$. davidiana than with P. tabulaeformis (Yao et al. 2017).

Cenococcum geophilum is common ectomycorrhizal fungus with widespread distribution in boreal or temperate habitats and connected with variety of spermatophyta hosts (De et al. 2018, Maíra et al. 2018). Furthermore, $C$. geophilum is the only ectomycorrhizal species appertain to the clade Dothideomycetes (Obase et al. 2016). Recent studies have shown that mycorrhizal fungi is one of pathogenic fungi, and use effectors with a small secreted protein (SSPs) as the molecular keys to promote symbiosis between plants and fungi (Kamel et al. 2017). The species of bacterial classes on the surface of ectomycorrhizae root system were significantly more than that of nonECM root system (Sakoda et al. 2018). C. geophilum is currently recognized as an ectomycorrhizal fungus with strong drought tolerant character (Fernandez and Koide 2013), and it is also one of the most indigenous ectomycorrhizal fungi in Inner Mongolia (Yao et al. 2017).

In the present study, five $C$. geophilum strains were used to inoculate $O$. davidiana and $P$. tabulaeformis seedlings. This study would provide the theoretical basis for vegetation restoration afforestation of Daqing Mountain and the foundation of mycorrhizal biological application technology in Inner Mongolia.

*Author for correspondence: <yaoqingzhi@imau.edu.cn>. 


\section{Materials and Methods}

Daqing Mountain is located in the middle of the Yinshan Mountains (Long 109 ${ }^{\circ} 46^{\prime} \mathrm{E}$ to $113^{\circ} 04^{\prime} \mathrm{E}$, Lat $40^{\circ} 34^{\prime} \mathrm{N}$ to $41^{\circ} 18^{\prime} \mathrm{N}$ ) in central Inner Mongolia. $O$. davidiana Seeds were collected from healthy trees on Daqing Mountain $(1,600 \mathrm{~m})$ whereas $P$. tabulaeformis seeds were purchased from a commercial seed company in Inner Mongolia.

$\mathrm{CgSO}_{1}, \mathrm{CgSB}_{2}$ and $\mathrm{CgSPOP}_{2}$ were isolated from $C$. geophilum sclerotia in the rhizosphere soil of $O$. davidiana, Betula platyphylla and Populus davidiana. $\mathrm{CgO}_{5}$ was isolated from the ectomycorrhizal root tissue of $O$. davidiana. $\mathrm{Cg}_{5}{ }^{\#}$ was introduced from France.

$C$. geophilum strains inoculants and $O$. davidiana and $P$. tabulaeformis seedlings for testing were prepared using the method described by Bai et al. (2009).

Six levels (five strains and one control) were tested ten times. Approximately $30 \mathrm{ml}$ of the fungi agent was then inoculated into the root system. In the Control (no live fungi inoculation) 6 $\mathrm{ml}$ of inoculum was taken per strain, mixed, sterilized at $121^{\circ} \mathrm{C}$ for $60 \mathrm{~min}$, and added to the seedling side. All containers were randomly placed in a growth chamber, cultured in the dark for one day, and placed in a light culture chamber $\left(23\right.$ to $\left.25^{\circ} \mathrm{C}\right)$. Hoagland nutrient solution were applied every 30 days to ensure the necessary nutrition of the seedlings.

Six months after transplanting, the seedlings of every 5 treatments were randomly selected to observe the mycorrhizal infection rate. Mycorrhizal infection rate $(\%)=($ mycorrhizal number/total root number) $\times 100$. The stem diameter and biomass were measured. The stem diameter and biomass of the root ring were measured. At the same time, according to the list given by Ageer $(1999,2006)$ the morphological and anatomical characteristics of mycorrhiza are described. Twoway analysis of variance (ANOVA) was used to determine whether C. geophilum significantly affected the influencing variables (ECMF infection rate, height, stem diameter, and dry weight) of seedlings.

\section{Results and Discussion}

After 6 months of inoculation, the unique mycorrhizae morphology for each strain on $O$. davidiana seedlings was studied. The infection rates were $45-48.1 \%$, all reached the fourth-level infection rate. The mycorrhizae morphology were studied for only $\mathrm{CgSO}_{1}$ and $\mathrm{SPOP}_{2}$ strains on $P$. tabulaeformis seedlings, while the infection rates were only 10.3 and $12.4 \%$ respectively. The results highlighted that the $C$. geophilum colonization rate of $O$. davidiana and $P$. tabulaeformis seedlings were dependent on the different ectomycorrhizal fungi strains.

From Figs 1 and 2 it was apparent that $\mathrm{CgSPOP}_{2}$ and $\mathrm{CgSO}_{1}$ strains formed typical ectomycorrhizal fungi. Moreover, the mycorrhizae morphology on $P$. tabulaeformis and $O$. davidiana was similar. Morphology of $O$. davidiana (Fig. 1A) and P. tabulaeformis (Fig. 2A) is hydrophilic, monopodial-pinnate or unramified, blank, $4-6 \mathrm{~mm}$ long, $0.4-0.6 \mathrm{~mm}$ diam., unramified ends inflated, with abundant dark rigid emanating hyphae, no rhizomorph, with rigid mycelium radially projecting from the surface, not smooth, shiny.

Mantle in plain view of $O$. davidiana (Fig. $1 \mathrm{~B}$ and C) and P. tabulaeformis (Fig. 2B and C) is plectenchymatous mantles, hyphae star-like arranged and tightly glued together (Type G), membranaceously brownish, and cell wall thick $(4.0-6.0 \mu \mathrm{m})$, with simple septa.

Effects of adding five $C$. geophilum strains on the response variables of $O$. davidiana seedlings were significant $(\mathrm{p}<0.05)$. The height of mycorrhizal seedlings increased by 49.6 $65.9 \%$. The stem diameter increased by $14.9-21.9 \%$. The number of lateral roots increased by $21.7-34.8 \%$. The dry weights of the seedlings of the aboveground portion increased by 51-66\%. The dry weights of the seedlings of the underground portion increased by $108.1-135.5 \%$. The 

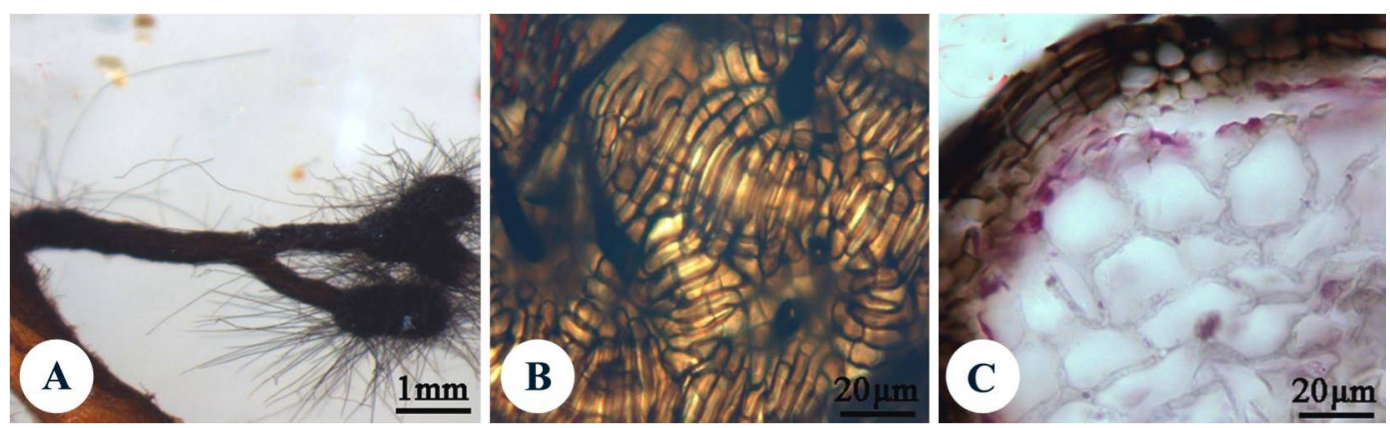

Fig. 1. Morpho-anatomical features of ectomycorrhizae on roots of Ostryopsis davidiana. A: External morphological features; B: Plan view of ectomycorrhizal mantle; C: Transverse section of ectomycorrhiza
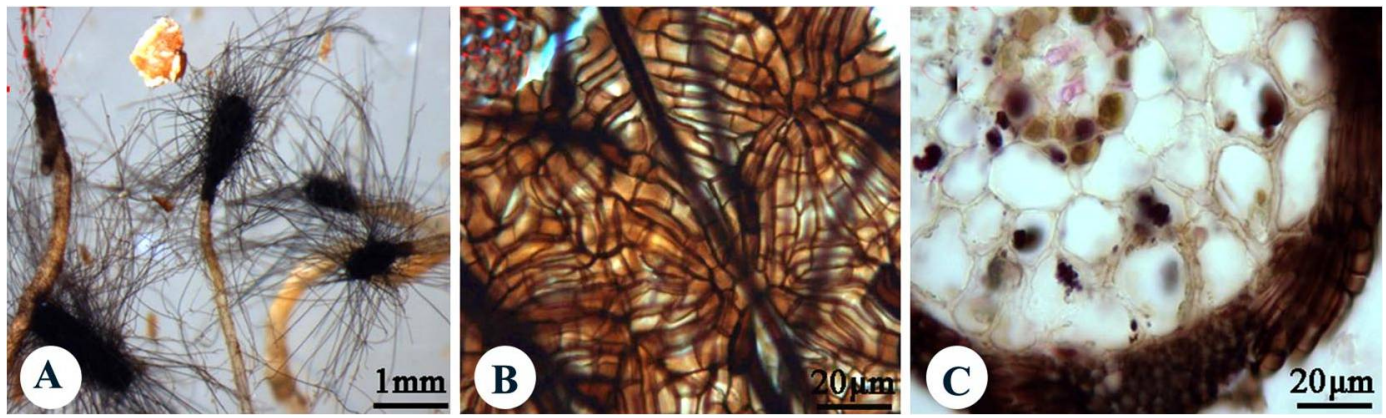

Fig. 2. Morpho-anatomical features of ectomycorrhizae on roots of Pinus tabulaeformis. A: External morphological features; B: Plan view of ectomycorrhizal mantle C: transverse section of ectomycorrhiza

increase in total dry weight is all around $80 \%$. The ratio of root to shoot ratio increased significantly. The relative water content increased in the range of 4.9 to $8.5 \%$ (Table 1).

Table 1. Effects of Cenococcum geophilum on the Growth of seedlings of Ostryopsis davidiana.

\begin{tabular}{lccccccc}
\hline Treatment & $\begin{array}{c}\text { Height } \\
(\mathrm{cm})\end{array}$ & $\begin{array}{c}\text { Stem } \\
\text { diameter } \\
(\mathrm{mm})\end{array}$ & $\begin{array}{c}\text { Lateral } \\
\text { root } \\
\text { numbers }\end{array}$ & $\begin{array}{c}\text { Dry } \\
\text { mass }(\mathrm{g})\end{array}$ & $\begin{array}{c}\text { root-shoot } \\
\text { ratio(mass/ } \\
\text { mass })\end{array}$ & $\begin{array}{c}\text { Relative } \\
\text { water } \\
\text { content }\end{array}$ & $\begin{array}{c}\text { ECMF } \\
\text { infection } \\
\text { rate }(\%)\end{array}$ \\
\hline $\mathrm{CgSO}_{1}$ & $19.8^{\mathrm{a}}$ & $2.78^{\mathrm{a}}$ & $31^{\mathrm{a}}$ & $1.661^{\mathrm{a}}$ & $0.835^{\mathrm{a}}$ & $89^{\mathrm{a}}$ & 45 \\
$\mathrm{CgSB}_{2}$ & $19.3^{\mathrm{a}}$ & $2.72^{\mathrm{a}}$ & $28^{\mathrm{a}}$ & $1.515^{\mathrm{a}}$ & $0.789^{\mathrm{a}}$ & $87^{\mathrm{a}}$ & 46.8 \\
$\mathrm{CgSPOP}_{2}$ & $21.4^{\mathrm{a}}$ & $2.62^{\mathrm{a}}$ & $28^{\mathrm{a}}$ & $1.608^{\mathrm{a}}$ & $0.727^{\mathrm{a}}$ & $88^{\mathrm{a}}$ & 48.1 \\
$\mathrm{CgO}_{5}$ & $20.8^{\mathrm{a}}$ & $2.62^{\mathrm{a}}$ & $29^{\mathrm{a}}$ & $1.657^{\mathrm{a}}$ & $0.738^{\mathrm{a}}$ & $86^{\mathrm{a}}$ & 49.2 \\
$\mathrm{Cg}_{5}^{\#}$ & $16^{\mathrm{b}}$ & $2.34^{\mathrm{a}}$ & $24^{\mathrm{b}}$ & $0.976^{\mathrm{b}}$ & $0.587^{\mathrm{b}}$ & $84^{\mathrm{b}}$ & 0 \\
$\mathrm{CK}$ & $12.9^{\mathrm{b}}$ & $2.28^{\mathrm{a}}$ & $23^{\mathrm{b}}$ & $0.882^{\mathrm{b}}$ & $0.572^{\mathrm{b}}$ & $82^{\mathrm{b}}$ & 0 \\
\hline
\end{tabular}

Different letters indicate significant differences $(\mathrm{p}<0.05)$.

As with $P$. tabulaeformis seedlings, $\mathrm{CgSPOP}_{2}$ and $\mathrm{CgSO}_{1}$ had different effects. The height of the mycorrhizal seedlings increased by 8.6 and $7.6 \%$. The stems diameter increased by 10.5 and $11.8 \%$. The number of lateral roots increased by 12.5 and $18.8 \%$. The total dry mass increased by 16.6 and $16.8 \%$. The root-shoot ratio (mass/mass) increased by 20.7 and $22 \%$ (Table 2). 
The present experiments showed that the mycorrhizal seedlings of $O$. davidiana and $P$. taebulaeformis grew better than non-mycorrhizal seedlings. However, compared with the exotic strains, the $O$. davidiana seedlings prefered to infect by native $C$. geophilum strains. Only the $\mathrm{CgSO}_{1}$ and $\mathrm{CgSPOP}_{2}$ strains infected the seedlings of $P$. tabulaeformis and the infection rates were low. This indicates that the affinity of $C$. geophilum and $P$. tabulaeformis was lower. On the other hand, it indicates that the strains from different environments had certain affinity to the same host. Because there are many factors which affect the mycorrhizal synthesis. The improvement of the colonization rate of $C$. geophilum to $P$. tabulaeformis remains to be further studied.

Table 2. Effects of Cenococcum geophilum on the Growth of seedlings of Pinus tabulaeformis.

\begin{tabular}{lccccccc}
\hline Treatment & $\begin{array}{c}\text { Height } \\
(\mathrm{cm})\end{array}$ & $\begin{array}{c}\text { Stem } \\
\text { diameter } \\
(\mathrm{mm})\end{array}$ & $\begin{array}{c}\text { Lateral } \\
\text { roots } \\
\text { number }\end{array}$ & $\begin{array}{c}\text { Dry } \\
\text { mass(g) }\end{array}$ & $\begin{array}{c}\text { Root-shoot } \\
\text { ratio(mass/ } \\
\text { mass })\end{array}$ & $\begin{array}{c}\text { Relative } \\
\text { water } \\
\text { content }(\%)\end{array}$ & $\begin{array}{c}\text { ECMF } \\
\text { infection } \\
\text { rate }(\%)\end{array}$ \\
\hline $\mathrm{CgSO}_{1}$ & $8.6^{\mathrm{a}}$ & $1.88^{\mathrm{a}}$ & $18^{\mathrm{a}}$ & $0.631^{\mathrm{a}}$ & $0.582^{\mathrm{a}}$ & $97^{\mathrm{a}}$ & 10.3 \\
$\mathrm{CgSB}_{2}$ & $7.9^{\mathrm{b}}$ & $1.66^{\mathrm{b}}$ & $16^{\mathrm{b}}$ & $0.571^{\mathrm{b}}$ & $0.513^{\mathrm{a}}$ & $95^{\mathrm{a}}$ & 0 \\
$\mathrm{CgSPOP}_{2}$ & $8.5^{\mathrm{a}}$ & $1.90^{\mathrm{a}}$ & $19^{\mathrm{a}}$ & $0.632^{\mathrm{a}}$ & $0.588^{\mathrm{a}}$ & $98^{\mathrm{a}}$ & 12.4 \\
$\mathrm{CgO}_{5}$ & $8.1^{\mathrm{b}}$ & $1.68^{\mathrm{b}}$ & $16^{\mathrm{b}}$ & $0.545^{\mathrm{b}}$ & $0.482^{\mathrm{a}}$ & $96^{\mathrm{a}}$ & 0 \\
$\mathrm{Cg}_{5}^{\#}$ & $8.1^{\mathrm{b}}$ & $1.66^{\mathrm{b}}$ & $17^{\mathrm{b}}$ & $0.555^{\mathrm{b}}$ & $0.511^{\mathrm{b}}$ & $97^{\mathrm{a}}$ & 0 \\
$\mathrm{CK}$ & $7.9^{\mathrm{b}}$ & $1.70^{\mathrm{b}}$ & $16^{\mathrm{b}}$ & $0.541^{\mathrm{b}}$ & $0.482^{\mathrm{b}}$ & $96^{\mathrm{a}}$ & 0 \\
\hline
\end{tabular}

Different letters indicate significant differences $(\mathrm{P}<0.05)$.

There were significant differences in seedling growth and mycorrhizal colonization rates of different tree species inoculated with different $C$. geophilum strains. Both $\mathrm{CgSO}_{1}$ and $\mathrm{CgSPOP}_{2}$ strains formed mycorrhizal structure with $P$. tabulaeformis and $O$. davidiana, and the colonization rate of $O$. davidiana was significantly higher than that of $P$. tabulaeformis. This is in consistent with the results of the previous field survey, indicating that the $O$. davidiana species have a stronger dependence on C. geophilum (Yao et al. 2017).

It was observed that the mycorrhizal colonization rate is influenced by the two factors of the host plants and the ECM fungi strains. The affinity and dependence of different plant species on different mycorrhizal fungi are very different. Therefore, in the process of afforestation, the best combination of tree species and mycorrhizal fungi should be screened firstly (Vopravil et al. 2014). Therefore, the C. geophilum strains are suitable for forestation and afforestation, which will have a profound impact on the construction of plantation in China, provide a scientific basis for the theory and practice of vegetation restoration, and has a strong promotion and application value.

\section{Acknowledgements}

The present work was supported by Inner Mongolia science \& technology plan [2019GG002].

\section{References}

Agerer R 1999. Anatomical characteristics of identified ectomycorrhizas: an attempt towards a natural classification. In: structure, function, molecular biology and biotechnology, Mycorrhiza, Berlin. pp. 633682.

Agerer R 2006. Fungal relationships and structural identity of their ectomycorrhizae. Mycol. Prog. 5: 67-107. 
Bai SL, Li GL, Liu Y, Dumroese RK and Lv RH 2009. Ostryopsis davidiana, seedlings inoculated with ectomycorrhizal fungi facilitate formation of mycorrhizae on Pinus tabulaeformis seedlings. Mycorrhiza 19: 425-434.

De MFP, Veneaultfourrey C, Vion P, Guinet F, Morin E, Barry KW, Lipzen A, Singan V, Pfister S, Na H, Kennedy M, Egli S, Grigoriev I, Martin F, Kohler A and Peter M 2018. Secretome analysis from the ectomycorrhizal ascomycete Cenococcum geophilum. Front. in Microbio. 9: 141.

Fernandez CW and Koide RT 2013. The function of melanin in the ectomycorrhizal fungus Cenococcum geophilum under water stress. Fungal Eco. 6: 479-486.

Kamel L, Tang N, Malbreil M, Clemente HS, Marquer ML, Roux C and Frei DFN 2017. The comparison of expressed candidate secreted proteins from two arbuscular mycorrhizal fungi unravels common and specific molecular tools to invade different host plants. Front. in Plant Sci. 8: 1-18.

Maíra DFP, Veneault-Fourrey C, Vion P, Fréderic G, Morin E and Barry KW 2018. Secretome analysis from the ectomycorrhizal ascomycete Cenococcum geophilum. Front. in Microbio. 9: 141.

Obase K, Douhan GW, Matsuda Y and Smith ME 2016. Revisiting phylogenetic diversity and cryptic species of Cenococcum geophilum sensu lato. Mycorrhiza 26: 529-540.

Sakoda S, Aisu K, Imagami H and Matsuda Y 2018. Comparison of actinomycete community composition on the surface and inside of japanese black pine (Pinus thunbergii) tree roots colonized by the ectomycorrhizal fungus Cenococcum geophilum. In: Microbial Ecology, Springer-Verlag Berlin Heidelberg, Berlin. pp. 1-10.

Vopravil J, Podrázský V, Khel T, Holubík O and Vacek S 2014. Effect of afforestation of agricultural soils and tree species composition on soil physical characteristics changes. Ekolo. 33: 67-80.

Wang Z, Yang H, Dong B, Zhou M, Ma L, Jia Z and Duan J 2017. Effects of canopy gap size on growth and spatial patterns of chinese pine (Pinus tabulaeformis) regeneration. Forest Ecology \& Manag. 385: 4656.

Yao QZ, Yan W, Zhao HY and Wei J 2017. Description and identification of Ostryopsis davidiana ectomycorrhizae in Inner Mongolia mountain forest of China. Austrian J. Mycol. 26: 17-25. 